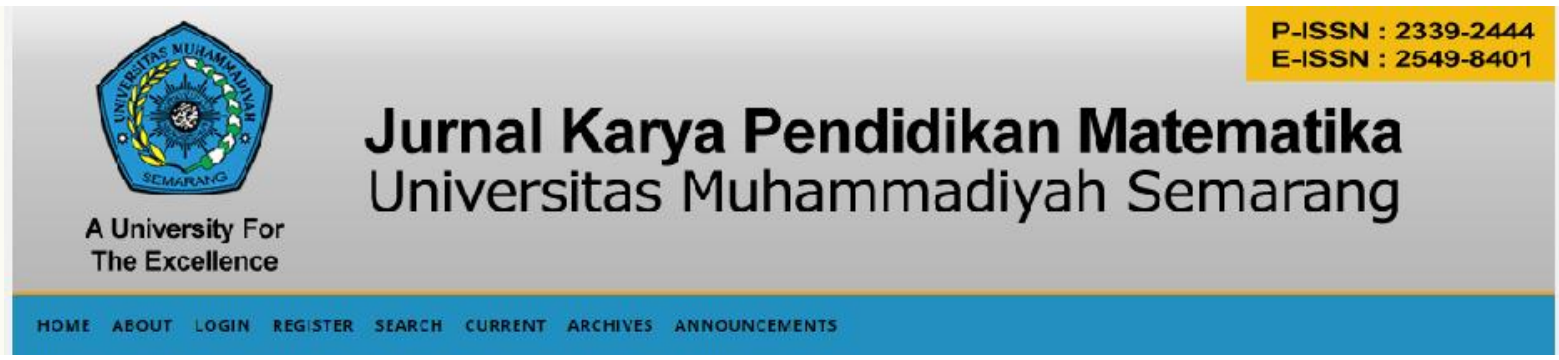

\title{
PENGARUH KEAKTIFAN DAN MOTIVASI TERHADAP HASIL BELAJAR SISWA DALAM PENERAPAN MODEL PEMBELAJARAN KOOPERATIF TIPE STAD MATERI TURUNAN FUNGSI PADA SISWA KELAS XI IS 2 SMA N 15 SEMARANG
}

\author{
Oleh: Sri Purwaningsih \\ sripurwaningsih.pajak15@gmail.com \\ SMA Negeri 15 Semarang
}

\begin{tabular}{ll}
\hline \multicolumn{2}{l}{ Article history } \\
\hline Submission & $: 12 / 9 / 2018$ \\
Revised & $:$ \\
Accepted & $: 26 / 9 / 2018$
\end{tabular}

Keyword:

activeness, motivation, learning outcomes, STAD

\begin{abstract}
Tujuan penelitian ini adalah untuk mnegetahui adakah pengaruh yang signifikan anatar keaktifan dan motivasi terhadap hasil belajar dalam implementasi model pembelajaran kooperatif tipe STAD materi turunan fungsi kelas XI IS 2 SMA Negeri 15 Semarang. Sehingga dalam penelitian ini yang merupakan penelitian studi kasus pada populasi siswa kelas XI IS SMA Negeri 15 Semarang dengan sampel siswa kelas XI IS 2. Variabel bebas dalam penelitian ini adalah kekaktifan dan motivasi belajar, sedangan variabel terikatnya adalah hasil belajar. Teknik pengambilan data pada kekatifan (X1) diperoleh dari lembar angket motivasi (X2) dan pada data hasil belajar (Y) diperoleh dengan cara tes. Untuk mendapatkan tujuan penelitian ini maka dilakukan uji regeresi linear ganda pada data yang diperoleh. Hasil analisis diperoleh bahwa persamaan regresi linear ganda $\hat{Y}=$ $15,114+0,203 \mathrm{X} 1+0,551 \mathrm{X} 2$ dengan Sig. $=1 \%<5 \%$, sehingga tolak $H_{0}$ dan terima $H_{1}$ artinya persamaan regresinya adalah linier. Selanjutnya besar pengaruh keaktifan dan motivasi terhadap hasil belajar dalam implementasi model pembelajaran kooperatif tipe STAD pada materi turunan fungsi sebesar $72,5 \%$.
\end{abstract}

\section{Pendahuluan}

Belajar (learning) merupakan suatu proses kompleks yang terjadi pada semua orang dan berlangsung seumur hidup, sejak ia masih bayi sampai ke liang lahat nanti (Sadiman dkk., dalam Warsita, 2008). Saat orang belajar, maka responnya akan menjadi lebih meningkat. Dimyati dan Mudjiono (2013) berpendapat bahwa belajar merupakan suatu perilaku.
Belajar dapat dilakukan dimana saja, kapan saja, usia berapa pun bisa belajar asalahkan memiliki niat dan motivasi untuk belajar. Dimana setiap orang memiliki tujuan tersendiri ketika mereka belajar. Salah satunya adalah untuk menambah pengetahuan mereka secara kognitif ataupun keterampilannya. Dalam proses belajar tentunya juga memerlukan aktifitas. Dimana semakin giat seseorang beraktifitas dalam belajar akan menghasilkan 
tujuan pembelajaran dengan baik pula. Sebaliknya jika aktifitas belajar seseorang kurang dalam mencari pengetahuan maka tujuan belajar yang ingin dicapaipun hasilnya kurang maksimal. Sama seperti hasil belajar. Dimana banyak sekali faktor-faktor yang mempengaruhi hasil belajar.

Faktor yang mempengaruhi hasil belajar antara lain keaktifan dan motivasi. Apalagi dalam pembelajaran matematika perlu sekali adanya motivasi dalam belajar guna memberikan semangat siswa dalam proses pembelajaran. Motivasi menurut Sadirman (2011) yaitu munculnya energi pada diri seseorang untuk mencapai suatu tujuan. Motivasi akan mempengaruhi kegiatan individu untuk mencapai segala sesuatu yang diinginkan dalam segala tindakan. Menurut Nasution (2010) menyatakan bahwa motivasi memiliki 3 fungsi, yaitu:

a. Mendorong manusia untuk berbuat;

b. Menentukan arah perbuatan, yakni ke arah tujuan yang hendak dicapai;

Menyeleksi perbuatan, yakni menentukan perbuatan-perbuatan apa yang harus dijalankan yang serasi guna mencapai tujuan tersebut, dengan menyampingkan perbuatan-perbuatan yang tak bermanfaat bagi tujuan tersebut.

Keaktifan juga memberikan pengaruh pada hasil belajar. Dimyati dan Mudjiono (2013) mengungkapkan bahwa kegiatan belajar mengajar akan terjadi apabila peserta didik lebih aktif sendiri dalam belajar. Sedangkan menurut Sulistyah et.al., (2011) keaktifan merupakan tuntutan yang penting dalam kegiatan belajar mengajar dimana peserta didik harus lebih aktif apabila ingin memdapatkan hasil yang baik.

Hasil refleksi dalam proses pembelajaran matematika di SMA Negeri 15 Semarang, diperoleh bahwa dalam proses pembelajaran materi turunan fungsi seringkali siswa kesulitan dalam menyelesaikan masalah pada implementasi turunan fungsi. Hal tersebut yang sering kali membuat siswa enggan untuk belajar materi turunan fungsi, maka akan Nampak motivasi siswa rendah. Karena motivasi siswa rendah maka keaktifan selama proses pembelajaran juga rendah. Guna menyelesaikan permasalahan tersebut maka perlu adanya implementasi pembelajaran yang bisa mengaktifkan siswa dalam belajar materi turuna fungsi. Salah satunya dengan menerapkan model pembelajaran kooperatif tipe Student Teams achievment Divisions (STAD).

Slavin (2008) menyebutkan bahwa "gagasan utama dari STAD adalah untuk memotivasi siswa supaya dapat saling mendukung dan membantu siswa lain dalam menguasai kemampuan yang diajarkan oleh guru belajar. Slavin (2009) menyebutkan bahwa "gagasan utama dari STAD adalah untuk memotivasi siswa supaya dapat saling mendukung dan membantu siswa lain dalam menguasai kemampuan yang diajarkan oleh guru.

Langkah-langkah penerapan dalam model pembelajaran kooperatif tipe $S T A D$ yang diterapkan dalam penelitian ini adalah 6 langkah sebagai berikut: (1) pembagian kelompok, (2) penyampaian materi, (3) diskusi kelompok, (4) pemberian kuis /pertanyaan, (5) penyimpulan, (6) pem-berian penghargaan (Wibowo, 2016). Dengan langkah tersebut maka kekatifan siswa dalam proses pembelajaran akan muncul. Selain itu dengan adanya diskusi kelompok akan memunculkan motivasi siswa selama proses pembelajaran.

Berdasarkan analisis permasalahan dan solusi dalam menyelesaikan masalah tersebut, maka perlu adanya penelitian untuk mengetahui seberapa besar pengauh keaktifan dan motivasi terhadap hasil belajar dalam implementasi model pembelajaran kooperatif tipe STAD pada materi turunan fungsi kelas XI IS SMA negeri 15 Semarang.

\section{Metode Penelitian}

Penelitian ini merupakan penelitian studi kasus pada siswa XI IS SMA Negeri 15 Semarang dengan teknik random sampling diperoleh sampel adalah siswa kelas XI IS 2. Variabel yang diukur tidak hanya hasil belajar saja, namun terdapat variabel bebas berupa keaktifan dan motivasi belajar siswa. Selanjutnya diukur apakah terdapat pengaruh antara variabel bebas dengan varibel terikatnya, jika ada seberapa besar pengaruh tersebut.

Subjek penelitian ini adalah siswa kelas XI IS 2 SMA Negeri 15 Semarang. Subjek tersebut diberi perlakukan berupa penerapan model pembelajaran kooperatif tipe STAD dalam proses pembelajaran matematika materi turunan fungsi.

Instrumen yang digunakan dalam penelitian ini adalah : (a) tes digunakan untuk mengukur hasil belajar siswa aspek kognitif, (b) Instrumen non tes digunakan untuk mengukur 
kekaktifan dan motivasi belajar siswa menggunakan skala likert. Dimana alat yang diukur untuk mengetahui keaktifan siswa menggunakan lembar observasi sedangkan alat ukur yang diguankan untuk mengetahui motivasi siswa adalah lembar angket minat siswa dalam proses pembelajaran berbasis masalah.

Berdasarkan tujuan penelitian yaitu mengetahui pengaruh keaktifan dan motivasi terhadap hasil belajar, maka analisis data yang digunakan adalah uji Regresi Linear Ganda. Analisis data tersebut menggunakan SPSS 17. Berikut langkah analisis yang dilakukan : (1) uji normalitas data hasil belajar sebagai uji prasyarat, (2) uji regresi linear ganda, (3) melihat nilai $\mathrm{r}$ square untuk mengetahui seberapa besar pengaruh keaktifan dan motivasi terhadap hasil belajar.

\section{Hasil Penelitian dan Pembahasan}

Hasil penelitian yang diperoleh dalam penerapan model pembelajaran kooperatif tipe STAD yang bertujuan untuk mengetahui keaktifan dan motivasi terhadap hasil belajar ini, diperoleh data mengenai : kekaktifan, motivasi dan hasil belajar. Data hasil belajar sebelum di berikan pada kelas ekperimen dilakukan terlebih dahulu validitas butir soal dan reliabilitas butir soal. Sehingga dari 5 soal uji coba semuanya dalam keadaan valid dan reliable. Sehingga intrumen dapat digunakan. Berikut rincian validitas dan reliabilitas soal.

\begin{tabular}{ccccc}
\multicolumn{6}{c}{ Tabel } & \multicolumn{3}{c}{ Analisis Soal Uji Coba } \\
\hline & $\begin{array}{c}\text { Kriteria } \\
\text { vald }\end{array}$ & $\begin{array}{c}\text { Kriteria } \\
\text { Tingkat } \\
\text { Kesukaran }\end{array}$ & $\begin{array}{c}\text { Kriteria } \\
\text { Daya } \\
\text { Beda }\end{array}$ & Reliabilitas \\
\hline 1 & Sangat & Sedang & Baik & Reliabel \\
& tinggi & sekali & \\
2 & Cukup & Sedang & Baik & \\
3 & Tinggi & Sedang & Baik & \\
4 & Cukup & Sedang & Baik & \\
5 & tinggi & Sedang & Baik & \\
& & & sekali & \\
\hline
\end{tabular}

Pada hasil uji coba lembar observasi keaktifan diperoleh data bahwa dari 20 butir pernyataan semuanya valid dan reliabel. Sehingga intrumen keaktivan bisa digunakan dalam kelas eksperimen.

Instrumen yang telah dinyataakan dalam keadaan valid dan reliabel, selanjutnya intrumen tersebut digunakan pada kelas ekperimen yang menerapkan model pembelajaran kooperatif tipe STAD dalam pembelajaran turunan fungsi. Data yang diperoleh selanjutnya di uji prasyarat terelbih dahulu, yaitu uju normalitas data gunan menentukan langkah selanjutnya dalan uji regresi linear ganda. Berikut hasil output SPSS 17 dalam uji noemalitas data hasil belajar, kekatifan dan motovasi.

Tabel 2 Uji Normalitas Data

One-Sample Kolmogorov-Smirnov Test

\begin{tabular}{|c|c|c|c|c|}
\hline & & Nilai & Keaktifan & Motivasi \\
\hline \multicolumn{2}{|l|}{$\mathrm{N}$} & 37 & 37 & 37 \\
\hline \multirow{2}{*}{$\begin{array}{l}\text { Normal } \\
\text { Parameters }\end{array}$} & Mean & 83 & 85 & 83 \\
\hline & Std. Deviation & 6.085 & 4.381 & 4.47 \\
\hline \multirow{3}{*}{$\begin{array}{l}\text { Most Extreme } \\
\text { Differences }\end{array}$} & Absolute & .162 & .171 & .189 \\
\hline & Positive & .161 & .132 & .103 \\
\hline & Negative & -.104 & -.122 & -.233 \\
\hline \multicolumn{2}{|c|}{ Kolmogorov-Smirnov Z } & .925 & 1.090 & 1.256 \\
\hline \multicolumn{2}{|c|}{ Asymp. Sig. (2-tailed) } & .099 & .101 & .097 \\
\hline
\end{tabular}

a. Test distribution is Normal.

b. Calculated from data.

Hasil tabel di atas menunjukkan bahwa nilai signifikansi untuk hasil belajar sebesar $0,099>5 \%$, sedangkan signifikansi data keaktifian sebesar $0,101>5 \%$ dan siginfikansi data minat sebesar $0,097>5 \%$. Jadi dapat dikatakan bahwa data nilai hasil belajar, keaktifan dan motivasi berdistribusi normal.

Berdasarkan hipotesis dalam penelitian ini yaitu : bahwa terdapat pengaruh yang signifikan anatar keaktifan (variabel X1) dan motivasi (variabel X2) terhadap hasil belajar siswa (variabel Y) maka hasil analisis regresi linear ganda diperoleh bahwa :

$H_{0}: b_{1}=0$ (tidak ada pengaruh kekatifan dan motivasi terhadap hasil belajar).

$H_{1}: b_{1} \not \pm 0$ (ada pengaruh kekatifan dan motivasi terhadap hasil belajar).

Kriteria : terima $H_{0}$ jika nilai signifikan $>5 \%$ dengan taraf signifikan yang ditetapkan peneliti sebesar 5\%. Untuk mengetahui nilainya dapat dilihat pada tabelberikut.

Tabel 3. Uji Keberartian

\begin{tabular}{|c|c|c|c|c|c|}
\hline \multirow[b]{3}{*}{ Model } & \multicolumn{3}{|c|}{ Coefficients ${ }^{\mathrm{a}}$} & \multirow[b]{3}{*}{$\mathrm{t}$} & \multirow[b]{3}{*}{ Sig. } \\
\hline & \multicolumn{2}{|c|}{$\begin{array}{l}\text { Unstandardized } \\
\text { Coefficients }\end{array}$} & $\begin{array}{c}\text { Standardized } \\
\text { Coefficients }\end{array}$ & & \\
\hline & B & Std. Error & Beta & & \\
\hline 1 (Constant) & 15.114 & 20.611 & & .733 & .001 \\
\hline Kekatifan & .203 & .277 & .152 & .733 & .000 \\
\hline
\end{tabular}

65

http://jurnal.unimus.ac.id/index.php/JPMat/index 
$\begin{array}{llllll}\text { Motivasi } & .551 & .307 & 373 & 1.795 .001 & \text { Berdasarkan tabel model summary }\end{array}$ a. Dependent Variable: Nilai diperoleh nilai $R^{2}=0,725=72,5 \%$ pengaruh

Hasil output SPSS di atasdiperoleh nilai Sig. pada keaktifan sebesar $0,00<5 \%$ sedangkan Sig. pada motivasi sebesar $0,001<$ $5 \%$ sehingga $\mathrm{H}_{1}$ diterima. Dapat disimpulkan bahwa terdapat pengaruh keaktifan dan motivasi terhadap hasil belajar. Selain itu dari tabel di atas juga bisa dilihat bahwa Persamaan regresi linear ganda yang dapat terbentuk adalah

$\hat{Y}=15,114+0,203 \mathrm{X} 1+0,551 \mathrm{X} 2$. Tahap selanjutnya adalah kita uji apakah persamaan tersebut linear, yaitu dengan uji kelinieran.

Uji kelinieran adalah untuk mengetahui kebenaran persaman $\hat{Y}=15,114+0,203 \mathrm{X} 1+$ $0,551 \times 2$ adalah persamaan linear. Berikut hipotesis untuk menguji kelinieran :

$H_{0}: \beta=0$ (persamaan regresi tidak linier)

$H_{1}: \beta \neq 0$ (persamaan regresi linier)

Kriteria : terima $H_{0}$ jika nilai signifikan $>5 \%$ dengan taraf signifikan yang ditetapkan peneliti sebesar 5\%. Untuk mengetahui nilainya dapat dilihat pada tabel ANOVA dibawah ini.

Tabel 4. Uji Kelinearan

\begin{tabular}{|c|c|c|c|c|c|c|}
\hline \multicolumn{7}{|c|}{ ANOVA $^{b}$} \\
\hline & Iodel & $\begin{array}{l}\text { Sum of } \\
\text { Squares }\end{array}$ & df & $\begin{array}{l}\text { Mean } \\
\text { Square }\end{array}$ & F & Sig. \\
\hline \multirow[t]{3}{*}{1} & Regression & 314.463 & 2 & 157.231 & 5.021 & $.001^{\mathrm{a}}$ \\
\hline & Residual & 997.537 & 34 & 30.228 & & \\
\hline & Total & 1312.000 & 36 & & & \\
\hline
\end{tabular}

a. Predictors: (Constant), Minat, Kekatifan

b. Dependent Variable: Nilai

Berdasarkan tabel ANOVA di atas diperoleh nilai Sig. $=1 \%<5 \%$, sehingga tolak $H_{0}$ dan terima $H_{1}$ artinya persamaan regresinya adalah linier.

Tahap selanjutnya untuk mengetahui besar pengaruh kekatifan dan motivasi belajar terhadap hasil belajar siswa implementasi model pembelajaran kooperatif tipe STAD dapat dilihat pada model summary tabel $\mathrm{R}$ square.

Tabel 5. Besar Pengaruh Model Summary

\begin{tabular}{|c|c|c|c|c|}
\hline $\begin{array}{l}\text { Mode } \\
1\end{array}$ & $\mathrm{R}$ & $\begin{array}{c}\mathrm{R} \\
\text { Square }\end{array}$ & $\begin{array}{c}\text { Adjusted R } \\
\text { Square }\end{array}$ & $\begin{array}{l}\text { Std. Error of the } \\
\text { Estimate }\end{array}$ \\
\hline 1 & $.804^{\mathrm{a}}$ & .725 & .701 & 2.145 \\
\hline
\end{tabular}

a. Predictors: (Constant), Minat, Kekatifan keaktifan dan motivasi belajar siswa terhadap hasil belajar sebesar $72,5 \%$ dan sebesar $27,5 \%$ dipengaruhi faktor lain. Hasil tersebut bahwa keaktifan dan motivasi sangat berpengaruh terhadap hasil belajar.

Adanya pengaruh yang signifakan antara kekaktifan dan motivasi tentunya tak terlepas dari penerapan model pemeblajaran kooperatif tipe STAD, dimana dalam proses pembelajaran siswa dikelompokkan secara heterogen dan kemundian diminta untuk menyelesaikan permasalahan secara bersamasama dalam satu kelompok. Hal inilah yang membuat mulai munculnya kekatifan siswa selama proses pembelajaran. Model pembelajaran STAD merupakan pilihan yang tepat untuk meningkatkan keterlibatan siswa secara aktif dalam kegiatan pembelajaran sehingga akan membuat siswa lebih meningkatkan aktivitas dalam berkomunikasi dengan guru dan teman kelompok belajarnya, peningkatan partisipasi aktif siswa tersebut akan berpengaruh terhadap hasil belajar siswa (Hikmah, 2015).

Selain itu penggunaan model kooperatif tipe STAD juga membuat motivasi siswa dalam belajar matematika akan terlihat. Sehingga dengan munculnya keaktifan dan motivasi belajar siswa dalam materi turunan fungsi yang menerapkan model kooperatif tipe STAD akan berpengaruh terhadap hasil belajar.

\section{Simpulan dan Saran}

Simpulan

Berikut simpulan yang dapat diperoleh dari analisis hasil penelitian :

1. Keaktifan dan motivasi belajar berpengaruh signifikan terhadap hasil belajar siswa kelas XI IS 2 SMA negeri 15 Semarang dalam implementasi model pembelajaran kooperatif tipe STAD materi turunan fungsi.

2. Besar pengaruh keaktifan dan motivasi terhadap hasil belajar dalam pembelajaran berbasis masalah adalah sebesar $72,5 \%$.

Saran

Perlu adanya penelitian lanjut untuk mengetahui variabel-variabel bebas lainnya yang dapat mempengaruhi hasil belajar siswa dalam pelaksanaan pembelajaran 
Jurnal Karya Pendidikan Matematika Vol 5 No 2 (2018) E ISSN : 2549 - 8401 P ISSN : 2339-2444

yang menerapkan model pembelajaran kooperatif tipe STAD.

\section{Daftar Pustaka}

Dimyati dan Mudjiono. (2013). Belajar dan Pembelajaran. Jakarta : Rineka Cipta.

Nasution. (2010). Berbagai Pendekatan dalam Proses Belajar dan Mengajar. Cetakan keduabelas. Bumi Aksara. Jakarta.Sardiman, A. M. (2011). Interaksi dan
Motivasi Belajar Mengajar. Jakarta: Grafindo Persada.

Nikmah, E.H, Fatchan, A., dan Wirahayu, Y.A. (2015). Model Pembelajaran Student Teams Achievement Divisions (STAD), Kekatifan dan Hasil Belajar Siswa. Universitas Negeri Malang.

Slavin, R. (2009). Cooperative Learning Teori, Riset dan Praktik. Bandung: Nusa Media.

Warsita, B.(2008).Teknologi Pembelajaran, landasan dan aplikasinya.Jakarta:Rineka Cipta. 